\title{
RECENT DEVELOPMENT IN THE RYEGRASSES
}

\author{
By L. CORKILiL, Senior Plant Breeder, Grasslands \\ Division, Department of Scientific and Industrial
} Research, Palmerston North.

Of the grasses used in sowing down pastures in New Zealand, those of the genus Lolium (the ryegrasses) are the most widely used, as one or other of them forms the basis of practically all seed mixtures. The characteristics of the ryegrass species and strains available to the farmer to-day are, in some respects, very different from those of strains available twenty years ago. So that a comparison between those and the present pedigree strains may be made, I shall deal briefly with the changes that have taken place over this period.

It had been generally known for a long time in New Zealand that there were large differences in perennial ryegrass strains, but it remained for Levy and Davies in the late 1920's to show the extent of these differences. From the study of ryegrass lines originat" ing from all over New Zealand they showed that widely different strains or ecotypes had naturally developed in New Zealand following the impact over a long time of climate, hybridisation, and different systems of farming, on the original strains imported into the country. Under a system of permanent grassland farming in regions of ample and well-distributed rainfall favourable to high grassland production, leafy, vigorous, truly perennial strains have developed ; whilst under temporary or short-rotation systems of farming in districts of lower rainfall short-lived strains have arisen. These have gradually eventuated from the practice of sowing a mixture of perennial and Italian ryegrass and harvesting for a seed crop in the first season. From hybridisation between the ryegrass species, sowing these mixtures, harvesting in the first season again, and the continued repetition of this practice, short-lived, free-seeding strains of ryegrass have eventually developed which possess the good characteristics of neither perennial nor Italian ryegrass. Levy and Davies showed that in the seed-producing areas of New Zealand the true perennial strains were confined to the Poverty Bay, Hawke's Bay, and to 
some extent, the Sandon districts, and the short-lived strains of "false" perennial ryegrass were characteristic of seed produced under arable farming conditions in the South Island.

Following their work on the identification and classification of these strains, the Government Certification Scheme was inaugurated under which the true perennial ryegrasses were certified whilst the "false" perennial strains were rejected. From some quarters, however, particularly from the arable farming areas of Canterbury, there was criticism of the certified strains, mainly on account of their relatively poor palatability compared with the "false" perennial strains. These, which had arisen from natural hybridisation with Italian ryegrass, had a certain degree of the Italian characteristics of rapid establishment and initial growth and palatability developed to a greater degree than in the true perennial ryegrass strains. In spite of the greater persistency and total annual production of the certified strains, these "false" perennial ryegrasses continued to be used, particularly where a system of short-rotation farming was practised. It was primarily to provide a better ryegrass to take the place of these "false" perennial strains that short-rotation or $\mathrm{H} 1$ ryegrass was bred.

When Levy and Davies made their survey they found very few true Italian ryegrass strains in the country. The reason for this was that Italian ryegrass lines imported into the country rapidly lost their identity through hybridisation with perennial ryegrass. Italian ryegrass was used for short-term pastures in arable regions or in mixtures with perennial ryegrass for short-term or permanent pasture mixtures. As Italian ryegrass is an annual and hybridises freely with perennial, it was not surprising that its identity was soon lost. Exactly the same fate befell lines of true Western Wolths ryegrass (a vigorous, shortlived variety of Italian) which had been imported into New Zealand.

Following the identification of these various ryegrass strains, their classification, and the establishment of the certification under which the best were certified as being true to type, a plant improvement programme was inaugurated at the Grasslands Division to-produce improved strains by plant breeding. Pedigree strains of perennial, Italian, and short-rotation ryegrass have now been produced and released into commerce. In this series of ryegrasses the main 
objective has been to breed highly producing pedigree strains to give a wide seasonal spread of production and for use in temporary, short-rotation, long-rotation, or permanent pastures. The characteristics of each of these ryegrasses will be discussed individually, particularly in relation to their use in extending, the season production of grassland.

It: has been the policy of the Grasslands Division to release into commerce a pedigree strain just so soon as. trials show that it is an improvement on the strains already on the market. Seed stocks are rapidly increased and these are distributed under the Government Seed Certification System. At the same time the plant breeding work is continued with the objective of making further improvement in the strain. As.nucleus stocks. of seed are continually- being produced by the Division, improved strains 'can be readily distributed. In this way the standard of certified seed can be gradually raised. Examples will later be quoted'of improvements which have been effected in bred strains.

\section{PERENNIAL RYEGRASS}

Of the "English grasses" imported into New Zealand by. the early immigrants probably the most valuable to the grassland economy of the better-class country is perennial ryegrass. It is the basic grass for all highly producing permanent pasture seeds mixtures. As mentioned earlier, since the first importation of perennial ryegrass a number of distinct strains or ecotypes have developed, some, truly perennial, others short-lived "false" perennial. In the. breeding of perennial. ryegrass, selection has been made from the true , perennial and emphasis has been applied to increase of leaf production and persistency together with resistance to leaf rust, which often severely attacks ryegrass in the late summer when there is little growth. In Table 1 the seasonal and total production of the pedigree strain is compared with that of the best "old pasture" strains of North Island and South Island origin. The ryegrass strains .were sown at $40 \mathrm{lb}$ per acre with, $3 \mathrm{lb}$ pedigree white clover per acre in 1/10 acre paddocks on April 10, 1947, at Palmerston North and rotationally grazed with sheep. The production in total dry matter per acre and ryegrass dry -matter per acre, to November 20, 1948, is shown in the table, 
TABLE 1

Seasonal production of perennial ryegrass' strains. at Palmerston North-lb total dry matter per acre and ryegrass dry matter per acre from $6 / 6 / 47$ to $20 / 11 / 48$.

\begin{tabular}{llrlllllll}
\hline Strain & $\begin{array}{l}\text { Dry } \\
\text { Matter w i n t e r }\end{array}$ & Spring & \multicolumn{2}{c}{ Sum } & Autumn & Winter & Spring & Total \\
\hline Pedigree & Total & 1081 & 4568 & 4979 & 3466 & 2359 & 5521 & 21974 \\
& Ryegrass & 868 & 3530 & 3613 & 2967 & 1932 & 4096 & 17005 \\
North Island & & & & & & & \\
"old pasture" & Total & 1040 & 3513 & 5182 & 3299 & 1518 & 4947 & 19499 \\
Routh Island & Ryegrass & 880 & 2966 & 4373 & 2905 & 1248 & 3643 & 16015 \\
"old pasture" & Total & 843 & 5386 & 3421 & 1833 & 1624 & 4635 & 17742 \\
& Ryegrass & 559 & 4304 & 2299 & 1310 & 1068 & 3061 & 12601 \\
\hline
\end{tabular}

The South Island strains which would be classed as a good "false" perennial ryegrass is higher producing than the pedigree strain in the first spring, but is much lower thereafter, due to its poor persistency. It can neither compete with pedigree perennial ryegrass as a permanent pasture strain nor with shortrotation ryegrass for a short-term pasture. There is little difference in the productivity of pedigree and North Island "old pasture" strains; the greatest difference is in their respective reactions to leaf -rust infection. The relative persistency and susceptibility- to leaf rust of these same three strains are shown by the figures from a replicated trial where observations on individual plants were recorded at Palmerston North in the 1947-48 season (Table 2).

\section{TABLE 2}

Persistency and leaf rust susceptibility of pedigree perennial ryegrass in comparison with "old pasture" strains (3 strains used in pasture production trial, 1947-48 season).

$\begin{array}{ccc}\text { Strain } & \text { Plants with leaf rust } & \begin{array}{c}\text { Plants surviving } \\ \text { per cent. }\end{array} \\ \text { per cent. } & 4 & 88 \\ \text { Pedigree } & 41 & 76 \\ \text { North Island "old pasture", } & 71 & 44\end{array}$

The superiority of the pedigree strain, particularly in resistance to leaf rust, is evident.

A similar comparison between the pedigree strain and a number of different ${ }^{-N}$ orth and South Island "natural" strains is shown in Table 3 . These dounts were made on blocks of spaced plants in 'the 1948-49 season. 
T A B L E 3

\section{Persistency and leaf rust susceptibility of pedigree perennial ryegrass compared with various natural strains (1948-49 season).}

\begin{tabular}{lccc}
\multicolumn{1}{c}{ Description } & $\begin{array}{c}\text { No. of } \\
\text { lines }\end{array}$ & $\begin{array}{c}\text { Plants with leaf } \\
\text { per cent. }\end{array}$ & $\begin{array}{c}\text { Plants } \\
\text { surviving } \\
\text { per cent. }\end{array}$ \\
$\begin{array}{l}\text { Pedigree } \\
\begin{array}{c}\text { North Island } \\
\text { "old pasture" }\end{array}\end{array}$ & 1 & 9 & 98 \\
$\begin{array}{c}\text { South Island } \\
\text { "old pasture" }\end{array}$ & 19 & 72 & 94 \\
$\begin{array}{c}\text { South Island } \\
\text { "false" perennial }\end{array}$ & 15 & 75 & 73 \\
\end{tabular}

In persistency, but particularly in lower susceptibility to leaf rust, the pedigree strain is superior to the "natural" strains. The North Island strains are definitely more persistent than the South Island strains, particularly the "false" perennial lines which "have a very low survival percentage after the first year.

The pedigree strain of perennial ryegrass is very suscpetible to blind seed disease, which in some seasons seriously reduces seed germination. There is some evidence that the. "false" perennial strains are less susceptible. Indeed the only plants located which are resistant to the disease are of rather poor agronomic type. Attempts are being made to breed a line of pedigree type but resistant to the disease by a series of crosses of these resistant plants to pedigree plants. It is, however, too early to forecast the results from this programme.

\section{ITALIAN RYEGRASS}

As already mentioned, Levy and Davies, in their survey of the ryegrass strains of New Zealand, found that Italian ryegrass lines were extremely mixed. Although Italian ryegrass lines had been regularly imported into the country, they rapidly lost their identity - through hybridisation with other ryegrass species or strains. It was not until the seed certification system was established that there was the means of ensuring that seed harvested would be true to the type of the 'seed sown. The basic. seed used to provide mother areas at the beginning of certification was imported seed. This was of the true Italian ryegrass typerapidly establishing, with high initial and winter production, palatable, wide-leaved and vigorous, and an 'annual. The plant-breeding objective with Italian ryegrass has been to retain these characteristics of early 
vigour and production but to add the ability to persist into the second year. What has been required is a strain of Italian which when sown with red clover as a temporary pasture will give high production in the first year, particularly in the winter and early spring," but will persist sufficiently well to give a red cloverItalian ryegrass mixture in the second year, rather than a pure red clover pasture with its consequent low winter carrying capacity.

The progress made in this direction is shown by the following figures based on spaced plant counts at Palmerston North and Lincoln. The plants at Palmerston North were planted on May 31, 1946, and recorded on May 27, 1947, and March 15, 1948, and those at Lincoln were planted on September 9, 1946, and recorded on May 11, 1948.

TABLE 4

Persistency of Italian ryegrass strains

\begin{tabular}{|c|c|c|c|}
\hline \multirow[b]{2}{*}{$\begin{array}{l}\text { Description } \\
\text { Certified non-pedigree }\end{array}$} & \multicolumn{3}{|c|}{ Persistency per cent. } \\
\hline & $\mathbf{w} / \mathbf{5} / \mathbf{4 7 -}$ & 15/3/48 & $11 / 5 / 48$ \\
\hline 1942 pedigree strain & 41 & 8 & 5 \\
\hline 1944 pedigree strain & 77 & 41 & 20 \\
\hline
\end{tabular}

The gradual build-up in persistency of the various pedigree strains is seen from these figures and the marked superiority of the latest pedigree strain over the original certified strain of non-pedigree origin. A comparison of the first- and second-year production of these two strains is given by a pasture measurement trial sown at Palmerston North on April 10, 1947, with ryegrass at $40 \mathrm{tb}$ per acre and pedigree broad red clover at $4 \mathrm{tb}$ per acre. The seasonal yields in th total dry matter per acre and ryegrass dry matter per acre are shown in Table 5.

TABLE 5

Seasonal production of Italian ryegrass strains' at Palmerston North-lb total dry matter per acre and ryegrass dry matter per acre from $1 / 6 / 47$ to $31 / 5 / 48$.

\begin{tabular}{llllrrrr}
\hline Strain & Dry & Winter & Spring & Summer & Autumn & Winter & Total \\
\hline Pedigree & Total & 2480 & 3325 & 2320 & 1396 & 2151 & 11672 \\
Certified & Ryegrass & 2405 & 2846 & 714 & 330 & 1611 & 1806 \\
Commercial & Total & 2179 & 3509 & 2380 & 1312 & 1663 & 11043 \\
& Ryegrass & 1991 & 2888 & 460 & 73 & 535 & 5947 \\
\hline & & $\mathbf{1 4 5}$ & & & &
\end{tabular}


In the first year the total production 'of the two strains is very similar, but the ryegrass production of the pedigree strain is 16 per cent. greater. than that of the certified commercial strain.. But it is in the second winter that the superiority of the pedigree strain is really shown, when both ryegrass dry matter and total dry matter of this strain are greater, the former by 182 per cent. and the latter by 29 per cent. Of the total dry matter produced in the second winter it is also significant that in the. certified commercial strain 28 per cent. is produced by useless "volunteer" Pod annua, which forms only ' 7 per cent. of the production from the plots sown with the pedigree strain.

In this trial the pedigree strain of Italian ryegrass is not only slightly more productive than the certified commercial strain in the first year, but is definitely more persistent and productive in the second winter. It is a high-producing grass eminently suited for winter and early spring green feed and for temporary pastures of one or two years' duration. When sown

with red clover as a special-purpose temporary pasture the Italian ryegrass produces during the winter, spring, and early. summer, while the red clover production is obtained in the late summer and autumn. The biennial nature of the pedigree strain of Italian ryegrass.makes it a good counterpart to red clover for a two-year pasture, as it persists sufficiently well to provide some grazing in the winter and early spring of the second year when the red clover is practically dormant. It should be remembered, however, that really high production and persistency will be obtained only under favourable conditions for growth, particuiarly in respect to soil moisture and fertility.

\section{SHORT ROTATION RYEGRASS}

In 1937 work was commenced on breeding a shortrotation strain of ryegrass from hybrids between perennial and Italian ryegrass. The objective was to produce- a strain with the combination of the characteristics of perennial and Italian ryegrass-high early production and 'palatability of Italian but with greater persistency from the perennial ryegrass parentage. We already had a good strain of pedigree perennial ryegrass for permanent pastures and Italian ryegrass for temporary pastures, and what was desired was a better ryegrass than the "false"! perennial strain. which was still used largely for pastures in short- 
rotation farming areas. A small supply- of stock seed of the strain produced was released as $\mathrm{H} 1$. ryegrass in 1943. It was soon apparent that this ryegrass. would have a wider application than for use only in shortterm pastures. It was also apparent that although it was more persistent than the Italian ryegrass available at that time, it would be much more valuable if its persistency could be improved while still retaining its characteristics of vigour, early production, and palatability. Since its release breeding work has been continued with this objective.

The seasonal productivity of short-rotation ryegrass under North Island and South Island conditions is shown in Tables 6 and 7, which are based on trials carried out at Marton and Lincoln. I am indebted to Mr P. B. Lynch, of the Department of Agriculture; for the figures of the Marton trial, and to $\mathrm{Mr} \mathrm{W}$. G. Thurston, of the Grasslands Division, for those from Lincoln.

\section{TABLE 6}

Average seasonal yields of perennial and short-rotation ryegrass in $1 \mathrm{tb}$ and total dry matter- and ryegrass dry matter per acre for four years at Marton.

\begin{tabular}{llccccc}
\hline Strain & $\begin{array}{c}\text { Dry } \\
\text { Matter }\end{array}$ & Spring & Summer & Autumn & Winter & Annual \\
\cline { 2 - 5 } Perennial & Total & 3920 & 2630 & 1984 & 1030 & 9564 \\
Short-rotation & Ryegrass & $\mathbf{2 8 8 0}$ & 1644 & 1616 & 836 & 6976 \\
& Total & $366 \mathrm{X}$ & $\mathbf{2 5 3 0}$ & 1915 & 1767 & $\mathbf{9 8 8 0}$ \\
& Ryegrass & $\mathbf{2 7 8 6}$ & $\mathbf{1 7 9 6}$ & 1380 & 1481 & $\mathbf{7 4 4 3}$ \\
\hline
\end{tabular}

TABLE 7

Average seasonal yields of perennial and short-rotation ryegrass in th total- dry matter and ryegrass dry mattes per acre for four years at Lincoin.

\begin{tabular}{|c|c|c|c|c|c|c|}
\hline Strain & $\begin{array}{l}\text { Dry } \\
\text { Matter }\end{array}$ & Spring & Summer & Autumn & Winter & Annual \\
\hline Perennial & Total & 1753 & 1298 & 470 & 159 & 3680 \\
\hline Shcrt-rotation & $\begin{array}{l}\text { Ryegrass } \\
\text { Total } \\
\text { Ryegrass }\end{array}$ & $\begin{array}{l}1356 \\
1895 \\
1563\end{array}$ & $\begin{array}{r}600 \\
1197 \\
620\end{array}$ & $\begin{array}{l}354 \\
398 \\
262\end{array}$ & $\begin{array}{l}140 \\
487 \\
453\end{array}$ & $\begin{array}{r}2450 \\
3977 \\
2898\end{array}$ \\
\hline
\end{tabular}

In both trials the ryegrasses were sown at $40 \mathrm{fb}$ per acre together with pedigree white clover at $3 \mathrm{lb}$ per acre, while at Lincoln $4 \mathrm{Ib}$ per acre of pedigree Montgomery red clover was also included. 
"In each trial the significant difference between the two ryegrasses is the superiority of short-rotation ryegrass in the winter months. In each trial, too, it is rather less productive in the autumn.

The effect of temperature and rainfall in the two districts on production is well shown in these tables. At Marton the average rainfall is 38 inches fairly evenly distributed throughout the year. At Lincoln it - is only 25 inches much less reliably distributed. Winter temperatures are- lower and: summer temperatures higher at Lincoln than at Marton. The annual production at Lincoln is less than half that at Marton. Approximately half this production at Lincoln is obtained in the spring. The winter production of short-rotation ryegrass is approximately 30 per cent. of its spring production, while the figure for perennial ryegrass is only 10 per cent. At Marton, where winter temperatures are higher, a greater proportion of the annual production is obtained in the winter with both perennial and short-rotation ryegrass, but the winterproduction of the latter is equal to more than 50 per cent. of its spring production, while that of perennial ryegrass is less than 30 per cent.

The persistency of short-rotation ryegrass is greater than that of Italian but poorer than perennial. Persistency under pasture conditions is dependent not only on the inherent persistency of the plant itself, but on environmental factors, some controllable and some not. Sufficient soil moisture, ample soil fertility, particularly nitrogen, and suitable pasture management are essential if high production and persistency are. to be maintained. The very nature of the shortrotation ryegrass plant. is such that it requires diferent grazing management. from that suited to perennial ryegrass if it is to produce and persist. Compared with perennial, the short-rotation ryegrass plant has a higher crown, is more erect in growth form, has larger and fewer tillers per square inch, and during its growing. season produces. a greater leaf bulk per tillercharacteristics which render the plant less able than perennial ryegrass to stand close and continuous defoliation.

The effect of grazing management on persistency is well shown in a trial carried out by $\mathrm{Mr} \mathrm{P}$. D. Sears at the Grasslands Division. Two paddocks were sown on March 20, 1'946, with a complex grass and clover mixture including $15 \mathrm{lb}$ short rotation and $20 \mathrm{tb}$ perennial ryegrass per acre., One paddock was continually 
grazed-with sheep and the other intermittently grazed when the pasture height- was 8 to 12 inches. Table 8 shows the percentage of each species' present in each paddock $1 \frac{1}{2}$ and $3 \frac{1}{2}$ years after sowing down.

\section{TABLE 8}

The percentage composition of pastures at Palmerston North under continuous and. intermittent grazing with sheep.

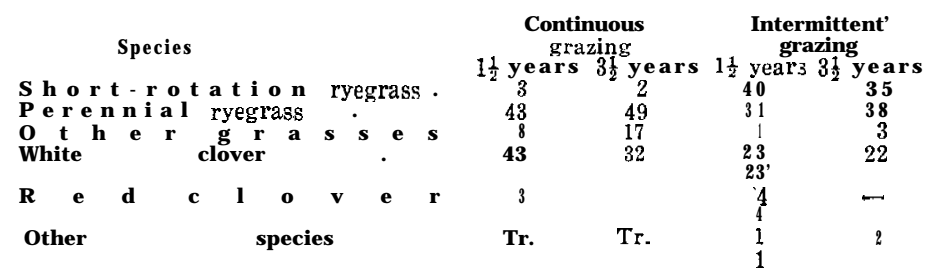

NOTE.-Both determinations made in October, a time of the year when the percentage of red clover is usually very low in a mixed sward.

Under the continuous sheep grazing the shortrotation ryegrass had practically disappeared in the second year, whilst under lenient intermittent, grazing it is still a co-dominant in the pasture in its fourth year.

The trial at Marton previously referred to gives some idea of the potentiality of short-rotation ryegrass to persist under suitable conditions of moisture, fertility, and pasture management. This trial has now been down for eight years, and to August 16, 1949, the paddock sown with short-rotation ryegrass has produced 72,206 ith dry matter compared with 68,997 形 from the paddock sown with perennial ryegrass. The production figures for these two paddocks in dry matter of ryegrass only for the last year to August 16 , 1949, have been 12,156 and 11,484 th respectively. In the period May 16, 1949, to October 4, 1949, the percentage of short-rotation ryegrass present in the pasture has averaged 82 .

Since the first seed of H1 ryegrass was released' further breeding has been along the lines of increasing its inherent persistency without losing -those characteristics of growth and palatability which have proved so valuable. The extent to which this has been accomplished is shown in Table 9. The figures are based on individual plant counts made at Palmerston North on lines planted on the field on July 4, 1946, and recorded 
on April 29, 1948; and on the same lines planted at Lincoln on September 9; 1946, and- recorded on May 11, $\begin{array}{llll}1 & 9 & 4 & 8\end{array}$.

\section{T A B L E 9}

Persistency in lines of short-rotation ryegrass at Palmerston North and Lincoln.

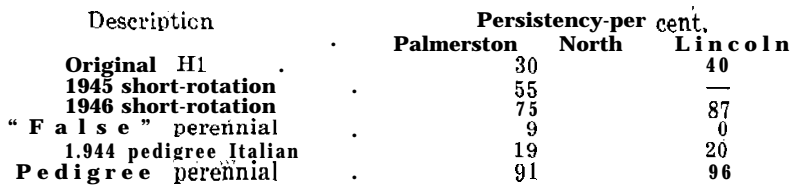

The improvement in persistency of the shortrotation rye-grass now going out into commerce compared with that released in 1943 is. evident. However, that does' not mean that the present strain of shortrotation ryegrass will ever approach perennial ryegrass in persistency under perennial ryegrass- management. It is still a vigorous, high-producing plant which requires particular conditions for its best growth and persistency:

In this review I have dealt only with those ryegrasses which' have been produced and 'are now in general use. Work is also being carried out on the possibility of breeding a long-rotation ryegrass intermediate in its characteristics between short-rotation and "perennial ryegrass, and also on an improved strain of Western Wolths ryegrass, an annual variety of Italian with 'greater winter production than this species., Whether' such strains will ultimately be produced and released. will depend on their performance relative to those pedigree ryegrasses already released.

There is now available to the farmer a range of ryegrasses with the potentialities for high and extended seasonal production. A knowledge of their charaeteristics'and limitations and the application of sound farming practice and intelligent, grazing management are, however, fundamental pre-requisites to the full exploitation of their inherent potentialities. 